\title{
SECONDARY TAX AND ITS EFFECT ON THE COST OF CAPITAL AND SHAREHOLDER VALUE OF SOUTH AFRICAN JSE LISTED COMPANIES
}

\author{
De Wet JHvH, Department of Financial Management, University of Pretoria and Das AD, KPMG \\ Pretoria
}

\begin{abstract}
Background: The introduction of a secondary tax on companies (STC) and the lowering of the normal income tax rate in 1993 constituted a dramatic change in the tax structure of South African organisations. The original intention of these changes was to encourage organisations to re-invest profits to make use of capital investment opportunities. It was also anticipated that these tax changes would lower the cost of capital of organisations.
\end{abstract}

Problem investigated: Announcements during the 2007 budget again raised questions about how the proposed changes in STC would affect the value of organisations. The impact of these tax changes has been the topic of some speculation in the absence of concrete research results to date.

Purpose: The purpose of this study was to investigate the effect of these tax changes and all subsequent changes since 1993 on the cost of capital and shareholder value.

Approach: A model of a hypothetical company, representing the 'average' listed South African organisation was used to determine the effect of the introduction of STC and the changes to the STC and company tax rate on the cost of capital and the value of the organisation.

Findings: The study found that, contrary to expectations, the tax changes actually caused the cost of capital to go up. Overall, the combined effect of the higher cost of capital and the lower company tax rate caused the theoretical value of organisations to increase, constituting an improvement of shareholder value.

Value of research: It is the first local study that endeavoured to analyse and quantify the impact of the introduction of STC and the lowering of the company tax rate on the cost of capital and the value of organisations.

Conclusion: The introduction of STC in and the lowering of the company tax rate in 1993, as well as changes to these two forms of taxes since then, seem to have been justified in terms of shareholder value creation.

Key words and phrases: Secondary Tax on Companies (STC); Weighted Average Cost of Capital (WACC); Economic Value added (EVA); Cost of Equity; Free Cash Flows (FCFs); Net Operating Profit (NOPAT).

\section{INTRODUCTION}

Shareholder value is a function of expected future cash flows, discounted at an appropriate cost of capital (Hawawini \& Viallet, 1999:380). An organisation's cost of capital determines not only the viability of capital investments, but also the value of the organisation's shares. Any factor that has a significant effect on the cost of capital needs to be considered carefully, as it will affect shareholder value. The secondary tax on companies (STC), which was introduced during 1993, is such a factor.

Announcements during the 2007 budget speech again focused the attention on STC (South African Revenue Service, 2007:1; Sizwe Ntsaluba VSP, 2007:1; Revenue Laws Amendment Bill, 2007:1; Du Preez, 2007:1 and Sasfin Frankel Pollak Securities, 2007:1). The effects of these tax changes on the cost of capital and the value of an organisation have been the topic of some speculation, but to date very little research has surfaced regarding the monetary benefits or disadvantages.

According to Davidson (1996:12) the stated objective for the introduction of STC was to encourage organisations to exploit investment opportunities. It was envisioned that the change in the 'mix' of taxes would discourage the payment of cash dividends, thereby giving an incentive for the reinvestment of profits in new capital projects. It was also anticipated that the increased capital investment would ultimately create more jobs. The introduction of STC was also expected to lower an organisation's cost of capital (Davidson, 1996:11). 
In order to assess whether the introduction of STC, together with the lowering of the normal company tax rate succeeded in meeting the initial objectives, a thorough investigation of the impact on the dividend policies, cost of capital and value of organisations is required. Each change to STC and the company tax rate subsequent to the introduction of STC need to be considered in order to determine how shareholder wealth was affected.

\section{STRUCTURE OF THE ARTICLE}

The structure of the article is designed to provide a framework for the research objectives, the research approach, the theoretical background on the cost of capital and value determination and the effects of the introduction of STC. The purpose of the research is to determine what impact the introduction of STC and the lowering of the company tax rate, as well as the changes to these rates, had on the cost of capital and shareholder value of listed South African organisations. The layout is arranged under the following headings:

- Research objectives;

- Research approach;

- Basic Theory underpinning cost of capital;

- Different views regarding cost of capital;

- Determination of value;

- Tax changes since introduction of STC in 1993;

- Summary of results;

- Implications; and

- Conclusion.

\section{RESEARCH OBJECTIVES}

The main objectives of this study are twofold, namely:

- To investigate whether the initial intentions with the introduction of STC and the lowering of the normal company tax rate actually materialised; and

- To determine what impact the introduction of STC and the lowering of the normal company tax rate had on the cost of capital and the value of organisations.

\section{RESEARCH APPROACH}

The research approach is to initially do a study of the basic theory and inputs regarding the determination of the cost of capital and the valuation of a company. From this study some inferences are drawn about how the STC might influence the cost of capital and company value. A case study using one or more listed organisations could have been one way to approach the analysis. However, in order to isolate only the effects of the tax changes and to keep all the other variables constant, it was decided to use a theoretical example of a company. Certain parameters were then set in order to build a profile of a theoretical company that is representative of the 'average' listed South African company. The impact of the introduction of STC, as well as each change in either the STC rate or the normal tax rate, are then determined before certain conclusions are made.

\section{BASIC THEORY UNDERPINNING COST OF CAPITAL}

The cost of capital is a vital ingredient in just about all strategic financial decision making. Typically, these decisions include:

- evaluating capital investments;

- determining optimal capital structures;

- valuations of company shares; and

- determining the economic value added (EVA) of a company (Correia, Flynn, Uliana \& Wormald, 2007:7-2). 
It therefore stands to reason that sound economic principles and dependable forecasting need to be combined with accurate calculations in order to estimate an organisation's cost of capital as reliably as possible. For consistent decision-making, unbiased by the specific form of finance used, a poolingof-funds approach is suggested, whereby a weighted average cost of capital ("WACC") is determined. The WACC is calculated after the component cost of each source of long-term finance (normally equity, preference shares and long-term debt) is determined and appropriately weighted according to the desired target cost structure (Firer, Ross, Westerfield \& Jordan 2004:474).

Where a given balance sheet is considered to represent the target capital structure, it is preferable to use market values, rather than book values, to determine the weights (Correia, Flynn, Uliana and Wormald 2007:7-14). According to Hawawini and Viallet (1999:320), Gitman (2006:511) and Wikipedia (2007:1) the weighted average cost of capital can be calculated by using the following formula:

WACC $=\left(\mathrm{w}_{e} \times \mathrm{K}_{e}\right)+\left(\mathrm{w}_{\mathrm{p}} \times \mathrm{K}_{\mathrm{p}}\right)+\left(\mathrm{w}_{\mathrm{d}} \times \mathrm{K}_{\mathrm{d}}\right)$
where
$\begin{array}{llll}\text { WACC }= & \text { weighted average cost of capital } \\ \mathrm{W}_{e} & = & \text { weight of equity } \\ \mathrm{W}_{\mathrm{p}} & = & \text { weight of preference shares } \\ \mathrm{W}_{\mathrm{d}} & = & \text { coight of debt } \\ \mathrm{K}_{e} & = & \text { cost of preference shares } \\ \mathrm{K}_{\mathrm{p}} & = & \text { cost of debt } \\ \mathrm{K}_{\mathrm{d}} & =\end{array}$

In order to address the impact of the introduction of STC and subsequent changes to the STC rate and the normal tax rate, careful consideration needs to be given to the effect of STC on each component cost of capital and ultimately, on the WACC. At this point it may be appropriate to reflect on the concept of cost of capital and the different views on how it could be determined.

\section{DIFFERENT VIEWS REGARDING COST OF CAPITAL}

The following description of cost of capital is given in CIMA (2005:178): "The cost of capital is the minimum return that a company should make on its own investments, to earn money out of which investors can be paid their return." This perspective may be in order to determine the cost of debt and of preference shares, but it would not be acceptable for equity. Shareholders derive their returns from both dividend payouts which is paid by the company and increases in the share price (capital growth), which is not paid by the company.

Two approaches (views) on how to determine the cost of capital are identified in CIMA (2005:178). According to the first approach, which can also be described as a direct approach or bottom up approach, the cost of capital is the after-tax cost the company pays for using a certain source of longterm capital. This approach is appropriate for both debt, where the component cost is the current after-tax interest rate, and for preference shares, where the component cost is the current rate on similar preference shares. The cost of preference shares is also equal to the effective cost percentage the company is paying, based on the current market price of the preference shares.

It is not possible to assign a direct cost to ordinary shares as the company has no obligation to pay any dividends to investors. Furthermore, capital growth, constituted by increases in the share price, is not paid out by the company. There may be some correlation between the percentage of profits retained in the company and future share price growth, but there may not necessarily be a good relationship. For instance, re-investing retained profits in projects with returns lower than the WACC will destroy value and therefore may cause a decline in the share price. Clearly, a different approach is required to handle the determination of the cost of equity.

The second approach views the cost of capital (specifically the cost of equity) as an opportunity cost. The cost of capital is then the minimum return required by investors to invest in a company of similar risk/return characteristics as the company under review (CIMA, 2005:178). This opportunity cost approach is therefore especially suitable to determine the cost of equity. 
There are two well-known models to determine the cost of equity, namely the dividend growth model and the capital asset pricing model. The so-called Gordon dividend growth model uses a simple valuation model based on future dividends and the current share price to estimate the cost of equity (Ross, Westerfield \& Jordan, 1993:490):

$\begin{array}{lll}\text { where } & = & \mathrm{D}_{1} / \mathrm{P}_{0}+\mathrm{g} \\ \mathrm{D}_{1} & = & \text { dividend expected for coming year } \\ \mathrm{P}_{0} & = & \text { current ex-dividend price per ordinary share } \\ \mathrm{g} & = & \text { expected constant future growth rate in dividends }\end{array}$

The requirement of a constant past or future dividend growth is rarely met in practice and it has already been pointed out that dividends alone do not fully represent the cost of equity capital. For the purposes of this article, these weaknesses rule out the dividend growth model as a reliable determinant of the cost of equity.

The capital asset pricing model (Damodaran, 1997:107; Palepu, Healy \& Bernard, 2000:12-14; Lund, 2002:483; Brigham \& Houston, 2004:364; Moyer, McGuigan \& Rao, 2005:199 and Brigham \& Daves, 2007:323) is a much better representation of the opportunity cost approach as it calculates the required rate to compensate the shareholder for the systematic (non-diversifiable) risk of the company. According to Killian (2005:56) this is also the approach most widely used in practice and preferred by McGregor BFA to determine the cost of equity for listed organisations. The cost of equity is determined as follows:

$\begin{array}{lll}\text { where } & = & R_{f}+\beta\left(R_{m}-R_{f}\right) \\ R_{f} & = & \text { risk-free rate, e.g. yield on government bond } \\ \beta & = & \text { beta-factor of share } \\ R_{m} & = & \text { average market return, e.g. on All-share Index }\end{array}$

Based on the following assumptions a hypothetical WACC can be determined before introducing the possible effects of STC.

\section{Assumptions}

1. Target weight equity

2. Target weight preference shares

3. Target weight long-term debt

4. Normal company tax rate before STC

5. Before tax cost of debt

6. After-tax cost of debt $12 \%(1-0,48)$

7. Current preference share rate

8. Risk-free rate

9. Beta

10. Market return

11. Market premium $\left(R_{m}-R_{f}\right)$

$\begin{array}{ll}= & 0,6 \\ = & 0,1 \\ = & 0,3 \\ = & 48 \% \\ = & 12 \% \\ = & 6,24 \% \\ = & 10 \% \\ = & 8 \% \\ = & 1,0 \\ = & 14 \% \\ = & 6 \%\end{array}$

All weights and components of cost of capital are selected to be more or less representative, on average, of listed South African organisations and the JSE Limited over the last number of years.

$$
\begin{array}{lll}
\mathrm{k}_{\mathrm{e}} & = & 8 \%+1,0(14 \%-8 \%) \\
\text { WACC } & = & 14 \% \\
& = & 0,6(14 \%)+0,1(10 \%)+0,3(6,24 \%) \\
& =11,27 \%
\end{array}
$$

In the next section the role of the WACC in determining the value of a company is discussed. 


\section{DETERMINATION OF VALUE}

To date, a range of methods have been developed to determine the value of a company. Typically any one of dividends (Brealy \& Myers, 2000:63 and Megginson, Smart \& Lucey, 2008:171), profits (Bodie, Kane \& Marcus, 2001: 422), cash flows (Lasher, 2003:73) or net assets (Gitman, 2006:351) can be used as a basis for a valuation. The selection of an appropriate valuation basis will depend on what basis is regarded as the main driver of value in a given valuation scenario. For the purposes of illustrating the impact of changes in the cost of capital and after-tax operating profits on the value of a company, a simple model, assuming zero growth, is used. The rationale behind this is that one would rather underestimate the calculation of value and the impact of the tax changes than exaggerate it.

$\mathrm{V} \quad=\quad$ FCF / WACC (Helfert 2000:383 and Brigham \&

Daves 2007:534)

With zero growth, FCF equals NOPAT, therefore:

$\mathrm{V}=$ NOPAT / WACC

where

$\begin{array}{lll}\mathrm{V} & = & \text { Value of the company as a whole } \\ \text { FCF } & = & \text { Free cash flows } \\ \text { NOPAT } & = & \text { Net operating profit after tax }\end{array}$

This model is based on the assumption that neither the dividend policy, nor the sources of long-term finance determine the value of the company. In other words, the value of the company is determined purely by its assets and their future earning power.

If it is assumed that a company had a before-tax operating profit of R100million in 1993 before the introduction of STC, the after-tax operating profit (NOPAT) would have been R52million after tax of $48 \%$. Using the WACC of $11,27 \%$ determined in the previous section, the value of the company at that time can be determined as follows:

V

$\begin{array}{ll}= & \text { NOPAT / WACC } \\ = & \text { R52m / 0,1127 } \\ = & \text { R461 million (rounded to nearest Rmillion) }\end{array}$

The effects of the introduction of STC and the subsequent changes to STC and the normal income tax rate on the cost of capital and the value of organisations will now be considered.

\section{TAX CHANGES SINCE INTRODUCTION OF STC IN 1993}

In the following sections the impact of the introduction of STC, as well as the concomitant changes in the company tax rate on the cost of capital and the value of organisations are discussed.

\section{Introduction of STC in March 1993}

During the 1993 budget, the then Minister of Finance, Derek Keys, announced a drop in the normal company income tax from $48 \%$ to $40 \%$ and introduced a secondary tax on companies (STC) of $15 \%$ on net dividends paid (Davidson, 1996:11). According to Davidson (1996:12) "the stated objective was to encourage organisations to exploit investment opportunities." This move embodied a disincentive to pay out dividends and it effectively left the company with the prerogative to decide what the effective combined tax paid would be and also what amount, if any, would be made available to ordinary shareholders by way of a dividend.

It is interesting to note that it was initially expected that the introduction of STC would lower an organisation's cost of capital (Davidson, 1996:11). The reasoning behind this argument is open for speculation. The lower expected dividend payouts could have been interpreted (wrongly, in the opinion of the authors) as a possible cause for a lower cost of capital, or perhaps the expected greater re-investment of profits could have resulted in savings in issuing costs and thereby lower the cost of capital. The expectation of a decrease in the cost of capital after the introduction of STC will be 
tested by making the appropriate tax adjustments to recalculate the WACC for the hypothetical company. Furthermore, the impact of the tax changes on the value of a company is determined.

Two important issues need to be highlighted at this juncture. Firstly, the introduction of STC cannot be evaluated in isolation. The combined effect of STC, along with the change in the normal income tax rate would have to be factored in simultaneously before conclusions can be drawn. Secondly, the issue of changing dividend payments brought about by the STC and its implications for signalling theory and the value of the organisation's shares is well worth pursuing through further research, but it falls outside the intent and scope of this article. The signalling theory of dividends states that shareholders may look at dividends as a more reliable indicator of the future prospects of a company than profits which can be manipulated more easily (Correia et al., 2007:20-4).

The impact of the introduction of STC of $15 \%$ and the lowering of the normal income tax rate from $48 \%$ to $40 \%$ on the cost of capital of the hypothetical company will now be considered. With an assumed cost of debt being $12 \%$, the after-tax cost of debt will now be $12 \% \times(1-0,40)=7,2 \%$. The cost of preference shares will now have to include STC of $15 \%$ and assuming the net preference dividend is kept at $10 \%$, the total cost becomes $10 \% \times 1,15=11,5 \%$. Taking an opportunity cost view of the cost of equity, the required return of shareholders would remain unchanged. This is so because the investor's perceived risk of the company is unaffected by the nature of the tax paid. Therefore the cost of equity, determined according to the capital asset pricing model, will remain the same. The WACC of the hypothetical company can now be determined as follows:

$$
\begin{array}{rll}
\text { WACC } & = & 0,6(14 \%)+0,1(11,5 \%)+0,3(7,2 \%) \\
& = & 11,71 \%
\end{array}
$$

When this result is analysed, it transpires that the WACC actually went up because of the smaller tax relief on the interest payments and the added STC on the preference dividends. The payout ratio did not affect the WACC at all, i.e. the WACC would have been the same if the payout ratio was $100 \%$ or zero.

Using a NOPAT of R60million (R100million before tax minus $40 \%$ tax) and the WACC of $11,71 \%$, the value of the company can be determined as follows:

$$
\begin{array}{lll}
\mathrm{V} & & \text { NOPAT / WACC } \\
& = & \text { R60m / 0,1171 } \\
& = & \text { R512million (rounded to nearest Rmillion) }
\end{array}
$$

The result shows that in spite of the increase in the cost of capital, the theoretical value of the company actually went up by $11 \%$, mainly on account of the drop in the normal tax rate.

\section{Increase of STC to 25\% and Reduction in Normal Tax to 35\% in June 1994}

Following the same reasoning as in the previous section, the impact of these changes can now be incorporated in the WACC calculation. The after-tax cost of debt becomes $12 \% \times(1-0,35)=7,8 \%$ and the cost of preference shares becomes $10 \% \times 1,25=12,5 \%$.

$$
\begin{array}{rll}
\text { WACC } & = & 0,6(14 \%)+0,1(12,5 \%)+0,3(7,8 \%) \\
& = & 11,99 \%
\end{array}
$$

These tax changes again resulted in the WACC actually increasing due to the same reasons mentioned in the previous section.

Using a NOPAT of R65million (R100million before tax minus $35 \%$ tax) and the WACC of $11,99 \%$, the value of the company can be determined as follows:

$$
\begin{array}{rlrl}
\mathrm{V} & & \mathrm{NOPAT} / \mathrm{WACC} \\
& = & \mathrm{R} 65 \mathrm{~m} / 0,1199 \\
& = & & \text { R542million (rounded to nearest Rmillion) }
\end{array}
$$


The result again shows that in spite of the increase in the cost of capital, the drop in the normal company tax rate caused the theoretical value of the company to go up by about $6 \%$.

\section{Decrease of STC to $12,5 \%$ in March 1996 and Normal Tax Kept at 35\%}

This change would only affect the cost of preference shares (now $10 \% \times 1,125=11,25 \%$ ) and the WACC can be calculated as follows:

$$
\begin{array}{lll}
\text { WACC } & =0,6(14 \%)+0,1(11,25 \%)+0,3(7,8 \%) \\
& =11,87 \%
\end{array}
$$

This time there is a slight reduction in the WACC by virtue of the effect of the decrease in STC on the cost of preference shares.

Using a NOPAT of R65million (R100million before tax minus 35\% tax) and the WACC of $11,87 \%$, the value of the company can be determined as follows:

$\begin{array}{lll}\mathrm{V} & & \text { NOPAT / WACC } \\ & = & \text { R65m / 0,1187 } \\ & = & \text { R548million (rounded to nearest Rmillion) }\end{array}$

This time, the slight decrease in the WACC caused the value of the company to increase by a little more than $1 \%$.

\section{Decrease in Normal Tax to 30\% in March 2000 and STC Kept at 12,5\%}

In this scenario, only the after tax cost of debt would change to $12 \% \times(1-0,3)=8,4 \%$.

$$
\begin{array}{rll}
\text { WACC } & =0,6(14 \%)+0,1(11,25 \%)+0,3(8,4 \%) \\
& =12,05 \%
\end{array}
$$

The slight increase in the WACC is attributable to the reduced tax benefit on the interest expense.

Using a NOPAT of R70million (R100million before tax minus $30 \%$ tax) and the WACC of $12,05 \%$, the value of the company can be determined as follows:

$$
\begin{array}{lll}
\mathrm{V} & & \text { NOPAT / WACC } \\
& = & \text { R70m / 0,1205 } \\
& = & \text { R581million (rounded to nearest Rmillion) }
\end{array}
$$

In spite of the increase in the WACC, the drop in the normal tax rate caused the value of the company to increase by just over $6 \%$.

\section{Decrease in Normal Tax to 29\% in March 2006 and STC Kept at 12,5\%}

Again, only the after-tax cost of debt would change to $12 \% \times(1-0,29)=8,52 \%$ and

$$
\begin{array}{rll}
\text { WACC } & =0,6(14 \%)+0,1(11,25 \%)+0,3(8,52 \%) \\
& =12,08 \%
\end{array}
$$

There is an almost negligible increase in the WACC, which is attributable to the reduced tax benefit on the interest expense.

Using a NOPAT of R71million (R100million before tax minus $29 \%$ tax) and the WACC of $12,08 \%$, the value of the company can be determined as follows:

$$
\text { V }
$$

$\begin{array}{ll}= & \text { NOPAT / WACC } \\ = & \text { R71m / 0,1208 } \\ = & \text { R588million (rounded to nearest Rmillion) }\end{array}$


In spite of the small increase in the WACC, the drop in the normal tax rate caused the value of the company to increase by a little more than $1 \%$.

\section{Decrease of STC to $10 \%$ Announced in March 2007, Effective from 1 October 2007, and Normal Tax Kept at $29 \%$}

During the 2007 Budget speech it was announced that the STC rate is lowered as of 1 October 2007 from $12,5 \%$ to $10 \%$. Along with the proposed change in STC rate, it was announced that STC would be replaced by a dividend tax at shareholder level in 2008 (Needham, 2007:1; Old Mutual, 2007:1, Temkin, 2007:1; SAICA, 2007:3 and Goga 2007:1). The proposals for 2008 are discussed in the next section. It was clearly stated that all distributions, including dividends on preference shares, would be liable for this withholding tax, which is to be administered by the company, but borne by the recipient. It is argued that organisations with preference shares would come under pressure to increase the preference dividend because the preference shareholders will have to pay the $10 \%$ tax and not the company (PSG Fund Management, 2007:2).

For the time being the effect of STC changing to $10 \%$ would cause the cost of preference shares to change to $10 \% \times 1,1=11 \%$ and this could be incorporated in the WACC calculation as follows:

$$
\begin{array}{rll}
\text { WACC } & =0,6(14 \%)+0,1(11 \%)+0,3(8,52 \%) \\
& =12,06 \%
\end{array}
$$

The marginal decrease in the WACC is obviously linked to the lower STC rate and its effect on the cost of preference shares.

Using a NOPAT of R71million (R100million before tax minus $29 \%$ tax) and the WACC of $12,06 \%$, the value of the company can be determined as follows:

$$
\begin{array}{lll}
\mathrm{V} & & \text { NOPAT / WACC } \\
& = & \mathrm{R} 71 \mathrm{~m} / 0,1206 \\
& = & \text { R589million (rounded to nearest Rmillion) }
\end{array}
$$

This time the small decrease in the WACC caused the value of the company to increase by about $0,2 \%$.

\section{Proposed for 2009 and Beyond}

In the 2009 and beyond scenario where there will be no STC payable by the company, but where the shareholders will bear the dividend tax burden, the STC adjustment to the cost of preference shares will fall away. Some organisations may increase their dividends on preference shares to compensate for the tax that would then be payable by the recipients of the dividends (PSG Fund Management, 2007:2). Ordinary shareholders who will then receive a smaller net dividend (because they are required to pay the withholding tax may expect higher capital growth in turn by virtue of the greater portion of profits reinvested in the company (no STC to be paid by the company). This is a reasonable expectation if it is taken into account that the company will then have the benefit of paying no STC. Under these conditions, no adjustment to the cost of equity will be required. The authors argue that what the ordinary shareholders may lose in terms of the lower net dividend (because they would have to pay the tax on dividends), they gain in terms of a greater expectation for capital growth (because the company can reinvest more profits as it does not have to pay the STC). The WACC would then be as follows:

$$
\begin{array}{lll}
\text { WACC } & =0,6(14 \%)+0,1(10 \%)+0,3(8,52 \%) \\
& =11,96 \%
\end{array}
$$

The small decrease in the WACC would be caused by the elimination of the effect of STC on the cost of preference shares. 
Using a NOPAT of R71million (R100million before tax minus $29 \%$ tax) and the WACC of $11,96 \%$, the value of the company can be determined as follows:

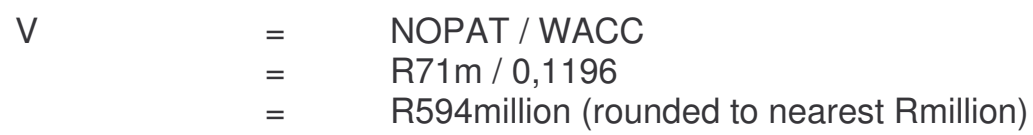

The small decrease in the WACC would cause the value of the company to increase by almost $1 \%$.

\section{SUMMARY OF RESULTS}

Figure 1 shows the impact of the introduction of STC in 1993 (and the lowering of the company tax rate) and the subsequent changes on the NOPAT and theoretical value of the hypothetical company. Figure 2 indicates the changes in the STC rate and the company tax rate.

Figure 1: Impact of tax changes on NOPAT and Value

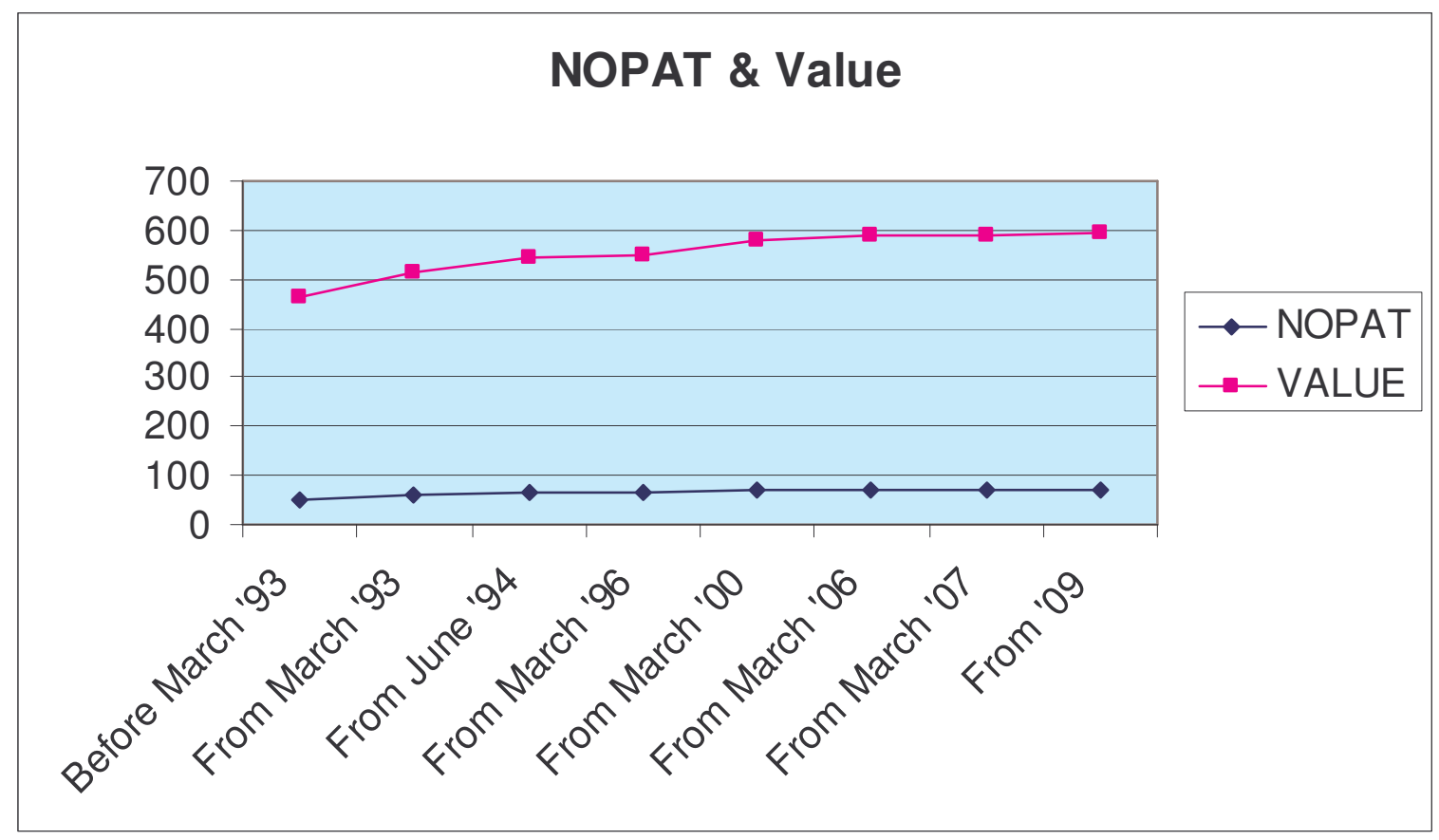


Figure 2: Changes in STC rate and company tax rate since 1993

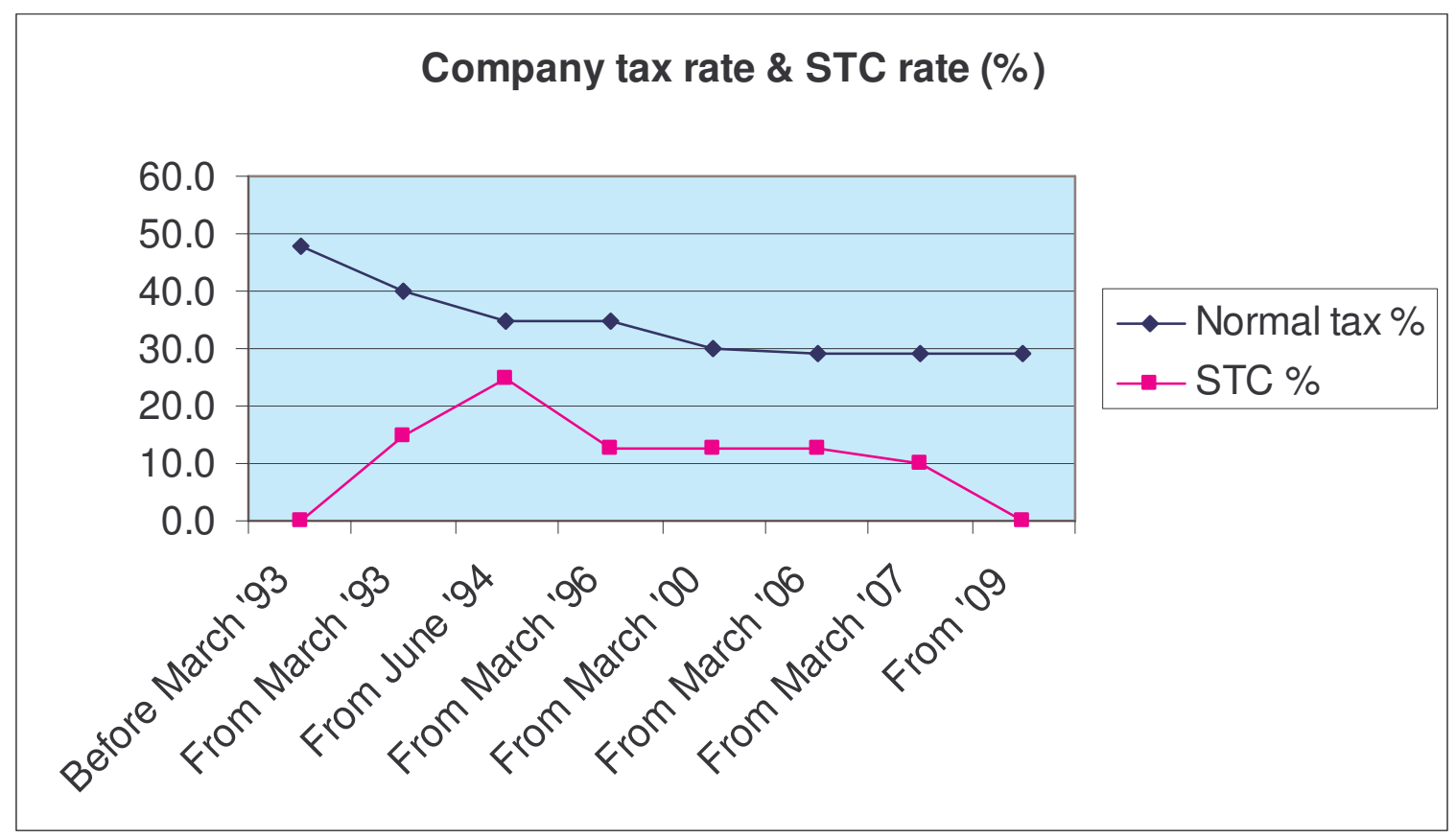

Table 1 contains a summary of the changes in STC and normal tax and its impact on the cost of capital.

Table 1: Summary of all tax changes and their impact

\begin{tabular}{|l|l|l|l|l|l|l|l|}
\hline Period & Normal & STC $\%$ & $\mathbf{k}_{\mathbf{e}}$ & $\mathbf{K}_{\mathbf{p}}$ & $\mathbf{K}_{\mathbf{d}}$ & WACC & Value \\
\hline tax $\%$ & & & & & & Rmil. \\
\hline Before March ‘93 & $48,0 \%$ & none & $14,0 \%$ & $10,00 \%$ & $6,24 \%$ & $11,27 \%$ & 461 \\
\hline From March '93 & $40,0 \%$ & $15,0 \%$ & $14,0 \%$ & $11,50 \%$ & $7,20 \%$ & $11,71 \%$ & 512 \\
\hline From June ‘94 & $35,0 \%$ & $25,0 \%$ & $14,0 \%$ & $12,50 \%$ & $7,80 \%$ & $11,99 \%$ & 542 \\
\hline From March '96 & $35,0 \%$ & $12,5 \%$ & $14,0 \%$ & $11,25 \%$ & $7,80 \%$ & $11,87 \%$ & 548 \\
\hline From March '00 & $30,0 \%$ & $12,5 \%$ & $14,0 \%$ & $11,25 \%$ & $8,40 \%$ & $12,05 \%$ & 581 \\
\hline From March '06 & $29,0 \%$ & $12,5 \%$ & $14,0 \%$ & $11,25 \%$ & $8,52 \%$ & $12,08 \%$ & 588 \\
\hline From March '07 ${ }^{\star}$ & $29,0 \%$ & $10,0 \%$ & $14,0 \%$ & $11,00 \%$ & $8,52 \%$ & $12,06 \%$ & 589 \\
\hline From '09** & $29,0 \%$ & none & $14,0 \%$ & $10,00 \%$ & $8,52 \%$ & $11,96 \%$ & 594 \\
\hline
\end{tabular}

* Implemented from 1 October 2007.

** Proposed.

\section{IMPLICATIONS}

The stated intention of the introduction of STC of $15 \%$ and the lowering of the normal tax rate from $48 \%$ to $40 \%$ was to encourage re-investment to exploit investment opportunities. The initial expectation was that these measures would not only decrease dividend payouts but also decrease the cost of capital.

Davidson (1996:22) found no significant change in the dividend payout ratios of the top 30 listed South African organisations from 1991 to 1993 after the introduction of STC and he concluded that STC failed as an incentive to retain earnings for investment. An up-to-date analysis of payout ratios of listed SA organisations, based on information provided by BFA McGregor, indicates a steady decline from a median of $40 \%$ in 1993 to a median of $26 \%$ in 2006, vindicating STC to a certain extent. Instead of lowering the cost of capital of organisations in South Africa, it appears as if these tax 
measures actually increased the WACCs, all other things being equal, by more than $0,5 \%$ from 1993 to 2007.

As typical free cash flow valuations have WACC in the denominator, this increase in the WACC did cause some measure of wealth destruction. However, this study found that the lowering of the normal company tax rate that accompanied the introduction and changes to STC had a greater positive impact. The net result was that shareholder value was actually enhanced; leading to the conclusion that these tax changes had a beneficial effect for business in general.

\section{CONCLUSION}

From the above it can be inferred that, contrary to initial expectations, the introduction of STC (and the lowering of the company tax rate at the same time) did not decrease the cost of capital of South African organisations. However, the initial drop in the company tax rate in 1993 did cause an increase in shareholder value and this, in turn, should have provided the incentive for greater capital project investment and job creation.

The most important insights coming to the fore in this study is that if an opportunity cost approach is followed, the cost of equity is unaffected by both the STC and the dividend payout ratio. The cost of preference shares is actually increased by the STC, even if its impact is limited because of the low average weight and use of preference shares in capital structures. The after-tax cost of debt is negatively impacted by decreases in the normal tax rate. The lower the tax rate, the smaller the tax benefit, the higher the net after-tax cost. The tax changes also lead to an increase in the NOPATs of organisations and this in turn lead to an increase in shareholder value.

Based on these findings, the introduction of STC and the lowering of the normal company tax rate were justified. Another related challenge would be to determine whether the increased re-investment of profits caused by the introduction of STC actually created new job opportunities. It is hoped that this article will contribute towards replacing speculation with greater clarity about the impact and effects of STC.

\section{REFERENCES}

Bodie Z, Kane A \& Marcus AJ. 2001. Essentials of Investments. $4^{\text {th }}$ ed. New York: Irwin.

Brealy RA \& Myers SC. 2000. Principles of Corporate Finance. $6^{\text {th }}$ ed. International Edition: Irwin.

Brigham EF \& Daves PR. 2007. Intermediate Financial Management. $9^{\text {th }}$ ed. Mason: Thomson.

Brigham EF \& Houston JF. 2004. Fundamentals of Financial Management. $10^{\text {th }}$ ed. Mason: Thomson.

CIMA. 2005. Strategic Paper P9 Management Accounting - Financial Strategy. Study Text. London: BPP Professional Education.

Correia C, Flynn D, Uliana E \& Wormald M. 2007. Financial Management. $6^{\text {th }}$ ed. Cape Town: Juta.

Damodaran A. 1997. Corporate Finance - Theory and Practice. New York: Wiley.

Davidson S. 1996. A note on the secondary tax on companies. South African Journal of Economic and Management Sciences, 18:11-23.

Du Preez L. 2007. Tax on dividends is not bad news for shareholders. Personal Finance - Tax Matters [Online] Available from: http://http.persfin.co.za/index.php?fSectionld=591\&fArticled=3699699

Firer C, Ross SA, Westerfield RW \& Jordan BD. 2004. Fundamentals of Corporate Finance $-3^{\text {rd }}$ South African ed. New York: McGraw-Hill. 
Gitman LJ. 2006. Principles of Managerial Finance. $11^{\text {th }}$ ed. Boston: Pearson International.

Goga M. 2007. Change in taxation of dividends. Ernst \& Young SA Tax Budget 2007.

Hawawini G \& Viallet C. 1999. Finance for executives. Cincinnati: Thomson.

Helfert EA. 2000. Techniques of Financial Analysis: A guide to value creation. Singapore: McGrawHill.

Killian TW. 2005. Designing an optimal capital structure. US Banker, September:54-58.

Lasher WR. 2003. Practical Financial Management. $3^{\text {rd }}$ ed. Mason: South-Western.

Lund D. 2002. Taxation, Uncertainty, and the Cost of Equity. International Tax and Public Finance, 9(4).

Megginson WL, Smart SB \& Lucey BM. 2008. Introduction to Corporate Finance. London: SouthWestern.

Moyer RC, McGuigan JR \& Rao RP. 2005. Contemporary Financial Management Fundamentals. Mason: Thomson.

Needham C. 2007. Preference shares knocked. Sunday Times Business Day. February 25.

Old Mutual. 2007. Dividend tax on shareholders. Old Mutual Budget Review [Online] Available from: http://www.oldmutual.co.za/markets/south-african-budget-2007/budget-summaries/budgetreview/shareholder-dividend-tax-,aspx

Palepu KG, Healy PM \& Bernard VL. 2000. Business Analysis \& Valuation - Using Financial Statements. $2^{\text {nd }}$ ed. Mason: Thomson.

PSG Fund Management. 2007 Budget comments: Dividend Tax.

Revenue Laws Amendment Bill. 2007. Explanatory Memorandum on the Revenue Laws Amendment Bill, 2007.

Ross SA, Westerfield RW \& Jordan BD. 1993. Fundamentals of Corporate Finance. Boston: Irwin.

SAICA 2007. 2007 Tax related budget proposals announced on 21 February.

Sasfin Frankel Pollak Securities. 2007. Preference shares and the Budget - a shift in the tax liability.

Sizwe Ntsaluba VSP Tax Department. 2007. Tax Newsletter. September 2007.

South African Revenue Service. 2007. Explanatory Note: STC Reforms [Online] Available from: http://www.sars.gov.za/media_releases/2007/Press\%20Statement\%20-

\%20ExplanatoryNote:STCReforms.

Temkin, S. 2007. STC dropped on 'lack of understanding' Business Day. February 27.

Wikipedia. 2007. Weighted Average Cost of Capital [Online] Available from:

http://en.wikipedia.org/wiki/Weighted_average_cost_of_capital 